\title{
How Functional are Greek Teaching Programs? Teacher Training and Job Placement in Greece's Most Struggling Profession
}

\begin{abstract}
By Theodore G. Zervas ${ }^{*}$
This paper examines teacher training in Greece and discusses whether Greek teacher training programs consider a functionalist approach to education. In other words, are Greek teacher training programs producing more teachers than the Greek school system and Greek society requires? If so, what steps have the Greek Ministry of Education taken to assure that teachers find work after completing their teacher training programs? Regardless of the student's achievement on national examinations, entry to teacher programs at the university level in Greece is primarily determined by the number of available places. In the last few decades there have been more teachers trained in Greece than the number of teacher jobs available. This paper is dived into several sections. It begins by discussing a functionalist perspective on education and how it applies to Greece, it follows by discussing past and current trends in education and teacher training in Greece, it then looks at teacher job placemen in Greece, and concludes with possible solutions to a saturated teacher labor market in Greece.
\end{abstract}

Keywords: Functionalism, Greece, Job placement, Teacher training.

From these facts it follows that each society sets up a certain ideal of man, of what he should be, as much from the intellectual point of view as the physical and moral; that this ideal is, to a degree, the same for all citizens; that beyond certain point it becomes differentiated according to a particular milieu that every society contains in its structure. Emile Durkheim

\section{Introduction}

In the spring of 2013, Greek teachers marched toward the Greek Ministry of Education in Athens demanding permanent positions in the Greek school system. For much of the 1990s Greece's major universities trained more teachers than the teacher labor market required. The outcome was an overabundance of jobless teachers, awaiting job placements in schools. Over the past few decades, Greek society has been confronted with substantial, social, cultural, and economic unrest. Due to the recent economic crises many schools in Greece were closed or merged with other schools.

* Associate Professor \& MAT Coordinator, North Park University in Chicago, Illinois, USA. 
Currently teacher-training programs in Greece do not address a changing global community, which includes such concerns as organization of labor, technology, and educating immigrant children. Unlike Greece, many European countries are already preparing teachers for a more technologically driven global community (Steiner 1996). Countries like France, Germany, Great Britain, and Italy, have all tied their teacher training programs to the labor market so as to assure that teachers find work after graduation. Greece on the other hand continues to produce more teachers than there are jobs available.

\section{Functionalist Perspective on Education}

Functionalism is a school of thought that attempts to explain social outcomes in terms of how the needs of a society are served and how a given society adjusts to changing social conditions (Pickering 2014). Functionalist theory contends that if one wants to understand a specific occupational practice or institution, one must consider the ways in which certain occupations and institutions serve society (Feinberg and Soltis 2004). The school is called functional because it serves society by contributing to its social and cultural existence. The school socializes children to adopt certain social and cultural norms, in order to help maintain and improve society. The school also serves the overall needs of society, by creating law abiding citizens that are prepared to contribute to the social, cultural, and economic growth of society. This could be by training members of society for particular jobs or other professions so that society maintains social and economic stability (Strouse 1997).

In the practical field of teaching and school administration, functionalism suggests efficiency in furnishing educational services so that children develop the attitudes, skills, and values needed to guarantee that society can achieve and maintain enough social solidarity to survive and function properly (Strouse 1997). Furthermore, education and more specifically schooling, is viewed as critical to political, social, and economic life, and is considered in plans and policies for national development (Abdi and Shibao 2008). From a functionalist perspective, education, whether universal or compulsory, is connected to the requirements of a modern industrial society, and education leads to modernity and progress.

When applied to Emile Durkheim's theory of functionalism, national and local educational systems seek to accomplish two major goals: 1 . to ensure that children are prepared to fill a wide array of social roles needed for a complex modern society and 2. to ensure that children acquire the skills needed to function and contribute to their society (Pickering 2004). In the case of teacher training programs in Greece, while newly trained teachers are sufficiently prepared for their roles as teachers at national schools, thier a fewer teacher jobs than required by Greek society (Kostakis 1987). In this case, teacher-training programs fall short in fulfilling their functionalist role to society. 


\section{Past and Current Trends in Teacher Training}

State run schooling for the most part, has been a modern phenomenon. With the articulation of the concept of the nation-state in Europe in the $19^{\text {th }}$ century came state driven programs to centralize and disperse outward state policy on what was to be taught in the nationalized school system (Cook 1974). Immediately after Greek Independence in 1827 the Greek school system was reorganized by the central government and administered by the Greek Ministry of Education (Massialas 1981).

Greece's newly found educational system would adopt a French model with echoes from an earlier Prussian model (Dimaras 1978). A two-tier system comprising elementary and secondary education was created. Elementary schools consisted of grades 1-4. Secondary schools were organized into a two-ladder system, which included the Hellenic schools and the gymnasia. The Hellenic schools taught grades 5-7. Gymnasia consisted grades 8-11. The Greek Orthodox Christian religion was also integrated into the school curriculum and the Greek Orthodox Church and state were linked when it came to matters on education.

By 1833 the king of Greece enacted the Primary and Communal Education Law, which established compulsory education for all children between the ages of five and twelve (Bouzakis 2005). The Pedagogical Institute of Athens was opened the following year with the mission of preparing teachers to teach at the national schools (Massialas 1981). The Pedagogical Institute was comprised of both men and women and teacher candidates were expected to teach a specific way, cover specific material, and prepare students to be loyal citizens. The school system and teacher training programs remained virtually unchanged for much of the $19^{\text {th }}$ and $20^{\text {th }}$ centuries (Antonaki-Dendrinou 1955).

By 1975 major reforms occur in the structure of education as a whole. Some of the changes for teacher training included 1. extending teacher training from two years to four years 2 . improvements to the national curriculum for teacher training programs and 3. reconsidering the admittance process into teacher training schools (Kazamias 1978).

Today, the Central Directorates for Primary and Secondary Education Personnel within the Ministry of Education is responsible for the selection and employment of teachers at all national primary and secondary schools. As of 2003 there were 52,788 teachers employed at the primary public schools, 35,789 teachers employed at the public lower secondary schools, and 22, 3325 employed at the public upper secondary schools (Stylianidou et al. 2004). It is unclear however on the exact number of trained teachers who are not employed in their field, but some estimates are as high as $30 \%$ (OECD 2015). 


\section{Education and Teacher Training Today}

Today, primary and secondary schooling in Greece follows similar models found in Western Europe. Education in Greece is compulsory for all children 6-15 years old; namely, it includes Primary (Dimotiko) and Lower secondary (Gymnasio) Education. The school life of the student however can start as early as the age of two and a half years (preschool education) in institutions (private and public) called Vrefonipiakoi Paidikoi Stathmi (crèches). In some Vrefonipiakoi Stathmoi there are also Nipiaka Tmimata (nursery classes), which operate along with the Nipiagogeia (kindergartens). Attendance at Primary Education (Dimotiko) lasts for six years, and children are admitted in the primary schools at the age of six. Along with the regular kindergartens (Nipiagogeia) and the Dimotika, all-day primary schools are in operation, with an extended timetable and an enriched curriculum. Postcompulsory secondary education consists of two school types: Eniaia Lykeia (Unified Upper Secondary Schools) and the Vocational Educational Schools (EPAL) (Pigiaki 1995). The duration of studies in Eniaia Lykeia (EL) is three years and two years (a'level) or three years (b'level) in the Vocational Educational Schools (EPAL) (CEDEFOP 2014).

Post-compulsory secondary education also includes Vocational Training Institutes (IEK), which provide a formal but unclassified level of education. Vocational schools are often more closely attached to the national labor market, by offering training for occupations that are in demand in the labor market (Paleocrassas et al. 2002). These institutes are not classified as an educational level, because they accept Gymnasio (lower secondary school) and Lykeio (upper secondary school) graduates.

Public higher education is divided into Universities and Technological Education Institutes (TEI). Students are admitted to these Institutes according to their performance on national level examinations, which take place at the second and third grade of Lykeio. Additionally, students can be admitted to the Hellenic Open University (an online/distance learning university) (Koustourakis et al. 2008).

With regard to teacher training, most elementary school teachers are trained at the various Pedagogical Departments found across Greece. It is worth noting that all national teacher programs conform to standards provided by the Greek Ministry of Education. This means that whether a teacher candidate attends the Pedagogical Department at the University of Athens or the Pedagogical Department at Aristotle University in Thessaloniki, all teacher candidates follow the same strict national curriculum and go through the same process in achieving their accreditation. Training for secondary school teachers is provided by the respective university departments, i.e., classical studies, physics, mathematic, history, literature, foreign languages, philology or theology department (ParagueliVoulioris 1999). In addition to core courses in the disciplines sought to teach, teacher candidates also complete courses in teacher instruction or teaching methods courses. Once placed in schools, candidates are expected to follow the Guidelines for the Curriculum and Instruction for Teaching 
Elementary and High School, prepared by the Greek Ministry of Education. The curriculum guide states that the main goal for teaching is the humanistic education of students, which will enable them to

1. Function intellectually, emotionally and morally

2. Become familiar with the diachronic values of the ancient Greek civilization

3. Receive civic education and

4. Develop intellectually (Kazamias 1965).

\section{Issues of Job Placement}

How teachers are placed in teaching positions in Greece is a unique process. In the past, teachers were placed according to a list or directory held by the Greek Ministry of Education. The list was based on the date for which a job application was submitted. In other words, the earlier the application was submitted the higher one would be on a priority list for placement at a school (Paragueli-Vouliouris 1999). Today, teacher appointments are based on the Supreme Council for Civil Personnel Selection exam (ASEP). How well a teacher does on the exam determines how quickly a teacher will be placed at a school. The exam also applies for substitute teaching.

There are individual lists for nursery, elementary, special education, and secondary teachers. Unlike the other grade levels and areas, the list for secondary school teachers is based according to specialty. Thus, separate applications are submitted for each of the specialty areas (ParagueliVouliouris 1999). The average age for a teacher placed in a teaching position is around thirty years old (Koustelios 2001).

So what do teachers do in the meantime while awaiting their placement at a school? Many displaced teachers work on advanced degrees at local or foreign universities, find temporary jobs outside of their fields, or work as tutors in frontistiria (cram schools) (Koustelios 2001). Many would agree that not working in one's field upon graduation would cause a host of problems. In the case of Greek teachers, many lose their enthusiasm for teaching and never enter the profession. Many of these teachers end up teaching in private schools, teaching as private tutors in frontistiria (cram schools), or working in other jobs outside of the teaching profession.

There is no question that Greece has a surplus of teachers. This calls for a serious discussion on the selection of teachers. Educational opportunities and the specific structures of educational systems are as consequential for mobility in labor markets as are the attributes of the individuals who make careers in those markets (Allmendinger 1997). To curb the saturation of teachers, the Greek government has set up career education programs. The career education programs were first established in 1976 and reorganized in 1985 and 2000 respectively (Buchbereger et al. 2000). The programs seek to provide students with information about professional opportunities and the 
demands on entering certain professions (Efthimiou 1998). They also assist young people on making realistic choices in what career they would like to pursue and the possibility of finding work in that career. In the case of teacher training programs in Greece, departments of education continue to admit more students than the Greek labor market demands.

\section{Finding a Solution}

Several approaches have been taken by the Greek Ministry of Education to find a solution to the issue of teacher placement and an overtly saturated teacher labor market. Ultimately, the Pedagogical Academies or teacher training schools could admit fewer students into their programs by raising the standards on national exams. Fewer teacher candidates in teacher training programs would allow for more opportunities for these candidates. This has been successful in countries like Finland and South Korea where fewer students are admitted into national teacher programs, and where candidates are able to find work after graduation (Paine and Schleicher 2011). A second approach that many policy makers have offered is training Greek teachers so that they could teach outside of Greece. The European Union (EU), an organization that Greece belongs to, is currently looking into standardizing teacher-training programs across its member states. In theory a teacher trained in Greece could inevitably teach in another EU member state. The EU Green Paper on Teacher Education states:

"Substantial changes of the context of the education and training (e.g. changes values, globalization of life and economy, organization of labor, the new information and communication technology) have impact on the professional tasks and roles of the profession and call for more substantial reforms of education and training in general (e.g. curricula and contents of teaching learning patterns of organization), and teacher education in particular" (Buchbereger et al. 2000)

Since many European Union member states are experiencing teacher shortages, many Greek trained teachers would be offered the option of teaching at a school in another member state. However, teacher education systems are typically shaped along cultural and national lines, (e.g. relating different perceptions on the role of the state with their impact on the roles of schools). Furthermore, teachers and teacher education in Greece has been strongly influenced by political ideology (e.g. conservative, socialist, and neo-liberal). Alleviating the Greek national context in schools by substituting it for a general European model is an issue many member states continue to struggle with today. After the economic crises in 2008 many teachers in who were waiting to be placed in schools in Greece, left Greece and sought opportunities elsewhere. 


\section{Conclusion}

Greek teacher programs are not functioning in terms of creating social and economic solidarity across the country. Functionalists argue that for a society to prosper, it requires to train its citizens to succeed in the general workforce. The Greek government however trains more teachers than it needs. Teachers could wait for more than ten years before being appointed to teach at a school. For some time unemployed teachers accepted this process, but with the current economic crises in Greece, teachers have grown impatient. This paper looked at teacher training programs in Greece and whether the Greek teacher academies, the Greek Ministry of Education and the Greek government consider a functionalist approach to education when preparing thier teachers. While reforms have been proposed on finding a solution to this problem none of the proposed solutions have been executed successfully thus far.

\section{References}

Abdi AA, Shibao G (Eds.) (2008) Education and Social Development: Global Issues and Analyses (Comparative and International Education: a Diversity of Voices). Rotterdam, NE: Sense Publishers.

Allmendinger J (1989) Educational Systems and Labor Market Outcomes. European Sociological Review 5(3): 231-250.

Antonaki-Dendrinou K (1955) Greek Education: Reorganization of the Administrative Structure. New York, NY: Unpublished Dissertation.

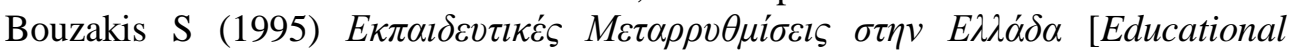
Reforms in Greece]. Athens: Gutenberg.

Buchbereger F, Campos BP, Kallos D, Sephenson J (Eds) (2000) Thematic Network on Teacher Education in Europe. Umea: Fakultetsnamnden for Lararutbildning, Umea Universitet.

CEDEFOP (2014) Vocational Education and Training in Greece. Luxembourg: Publications of the European Union.

Cook TG (1974) History of Education in Europe. New York, NY: Beekman Publishers.

Dimaras A (1978) The Movement of Reform: A Historical Perspective. Comparative Education Review 22(1): 11-20.

Efthimiou H (1998) The Problamatic of Comparative Teacher Education: Perspectives from Greece and the United States. College Park, MD: Unpublished Dissertation.

Feinberg W, Soltis JF (2004) School and Society. New York, NY: Columbia University Press.

Kazamias AM (1978) The politics of educational Reform in Greece: Law 309/1976. Comparative Education Review 22(1): 21-45.

Kazamias AM (1965) Tradition and Change in Education: A Comparative Study. Chicago, IL: University of Chicago Press.

Kostakis A (1987) Differences Among School Outputs and Educational Production Functions. Sociology of Education 60(4): 232-241. 
Koustelios AD (2001) Personal Characteristics and Job Satisfaction of Greek Teachers. International Journal of Educational Management 15(6/7): 354358.

Koutsorakis, Gerasimos, Panagiotakopoulos C, Vergidis D (1998) A Contribution to the Hellenic Open University: Evaluation of the Pedagogical Practices and the Use of ICT on Distance Education. The International Review of Research in Open and Distributed Learning 9(2): 1-18.

Massialas BG (1981) The Educational System of Greece. Washington, D.C.: U.S. Government Printing Office.

OECD (2015) Education at a Glance 2015: OECD Indicators. Retrieved from http://bit.ly/29J7mRT.

Paine SL, Schleicher A (2011) What the U.S. Can Learn from the World's Most Successful Education Reform Efforts. New York: McGraw Hill Research Foundation.

Paleocrassas S, Rousseas P, Vretakou V (2002) Secondary Education Graduates in the Labor Market: Evidence and career Education Policy Issues for Greece. Journal of Vocational Education and Training 54(2): 1-7.

Paragueli-Vouliouris D (1999) Evaluation of Teacher Education in Greece: A Political Demand of Our Time. TNTEE 2(2): 129-137.

Pickering WSF (Ed) (2014) Durkheim and Representations. London: UK Routledge.

Pigiaki P (1995) Fundamental Errors Made in the Design and Introduction of Career Education in Schools. International Journal of Vocational Education and Training 3(1): 33-50.

Steiner M (Ed) (1996) Developing the Global Teacher: Theory and Practice in Initial Teacher Education. London, UK: Trentham Books Ltd.

Strouse JH (1997) Exploring Socio-Cultural Themes in Education: Readings in Social Foundations. Columbus, OH: Merrill Prentice Hall Press.

Stylianidou F, Bagakis G, Stamovlasis D (2004) Attracting, Developing and Retaining Effective Teachers: OECD Activity Country Background Report for Greece. Paris: OECD Education Research Center. 